Supporting Information

Journal of Organic Chemistry

\title{
Improving Glycopeptide Synthesis: A Convenient Protocol for the Preparation of $\beta$-Glycosylamines and the Synthesis of Glycopeptides
}

\author{
Christian P.R. Hackenberger, Mary K. O'Reilly, and Barbara Imperiali*
}

Contents:

Experimental procedures....................S2-S5

Spectra................................S6 7

References................................S7 
General. All reagents, amino acids, and solvents were purchased from commercial suppliers and used without further purification. $\mathrm{CH}_{2} \mathrm{Cl}_{2}$ was distilled from $\mathrm{CaH}$ under argon. All other solvents were reagent grade and used as received. Unless otherwise noted, all reactions were carried out under argon using standard Schlenk and vacuum line techniques.

Crude Chitobiose: The preparation of crude chitobiose was performed according to previously published protocols. ${ }^{1}$ Commercially available chitin $(20 \mathrm{~g})$ from crab shells was digested with $125 \mathrm{~mL}$ concentrated $\mathrm{HCl}$ for 90 minutes under sonication. The black syrup was diluted with 1.5 $\mathrm{L}$ of ice and water before the mixture was stored overnight at $4{ }^{\circ} \mathrm{C}$. The resulting white powder was filtered, and then washed with $25 \mathrm{~mL}$ of $1 \mathrm{M} \mathrm{NaOH}$ solution followed by neutralization with water. The colloidal chitin was subsequently washed with $30 \mathrm{~mL}$ acetone and finally with $30 \mathrm{~mL}$ ethyl ether. The pale yellow powder was lyophilized to obtain $12.6 \mathrm{~g}$ of dry material. This colloidal chitin was used for the enzymatic reaction using commercially available chitinase from Streptomyces griseus (Sigma). Two reactions, each with $6.3 \mathrm{~g}$ of colloidal chitin, were performed. For each reaction, $34.8 \mathrm{mg}$ of chitinase (460 units $/ \mathrm{g}$, or an equivalent to 16 units) were added to a $100 \mathrm{~mL} 0.1 \mathrm{~N} \mathrm{Na}_{2} \mathrm{HPO}_{4}$ buffer solution at $\mathrm{pH} 6.4$ which contained the chitin. The mixture was stirred at $37^{\circ} \mathrm{C}$ for 15 days followed by filtration and lyophilization of the liquid. Each reaction produced approximately $5.8 \mathrm{~g}$ of crude chitobiose.

Fluorescence HPLC analysis of crude chitobiose: To evaluate the purity of crude chitobiose, particularly with respect to the presence of higher polymers of chitobiose, the material was labeled at the reducing terminus with anthranilimide and separated on a GlycoSep ${ }^{\mathrm{TM}} \mathrm{N}$ HPLC column (ProZyme, Inc.), which is a normal phase column. Detection was accomplished using a Waters 470 scanning fluorescence detector, with excitation at $330 \mathrm{~nm}$ and emission measured at $420 \mathrm{~nm}$. To prepare the dye labeling reagent, a $150 \mu \mathrm{L}$ aliquot of acetic acid was added to a 350$\mu \mathrm{L}$ aliquot of DMSO, and then a $100 \mu \mathrm{L}$ aliquot of this mixture was used to dissolve $5 \mathrm{mg}(0.4$ $\mu \mathrm{mol})$ of anthranilimide. The entire dye solution was added to $6 \mathrm{mg}(1 \mu \mathrm{mol})$ of sodium cyanoborohydride and mixed well to dissolve the reductant. An aliquot of $5 \mu \mathrm{L}$ of this reagent was then added to $1 \mathrm{mg}$ of crude chitobiose, and heated to $65^{\circ} \mathrm{C}$ for $2-4$ hours. Following the incubation, the reaction mixture was allowed to cool to room temperature, and post-labeling clean-up was accomplished by using a GlykoClean ${ }^{\mathrm{TM}} \mathrm{S}$ cartridge (ProZyme, Inc.) according to the manufacturer's instructions. HPLC was carried out using a linear gradient of 20 to $53 \%$ of 50 $\mathrm{mM}$ ammonium formate, $\mathrm{pH} 4.4$ in acetonitrile over 85 minutes, following an initial 5 minutes at $20 \%$ buffer in acetonitrile. The major peak in the HPLC trace elutes with the retention time of chitobiose (Figure 1). The minor peak at 20 minutes has the retention time of $N$ acetylglucosamine. The other minor peaks do not increase in size upon loading higher concentrations, and thus are considered to be in the background. 


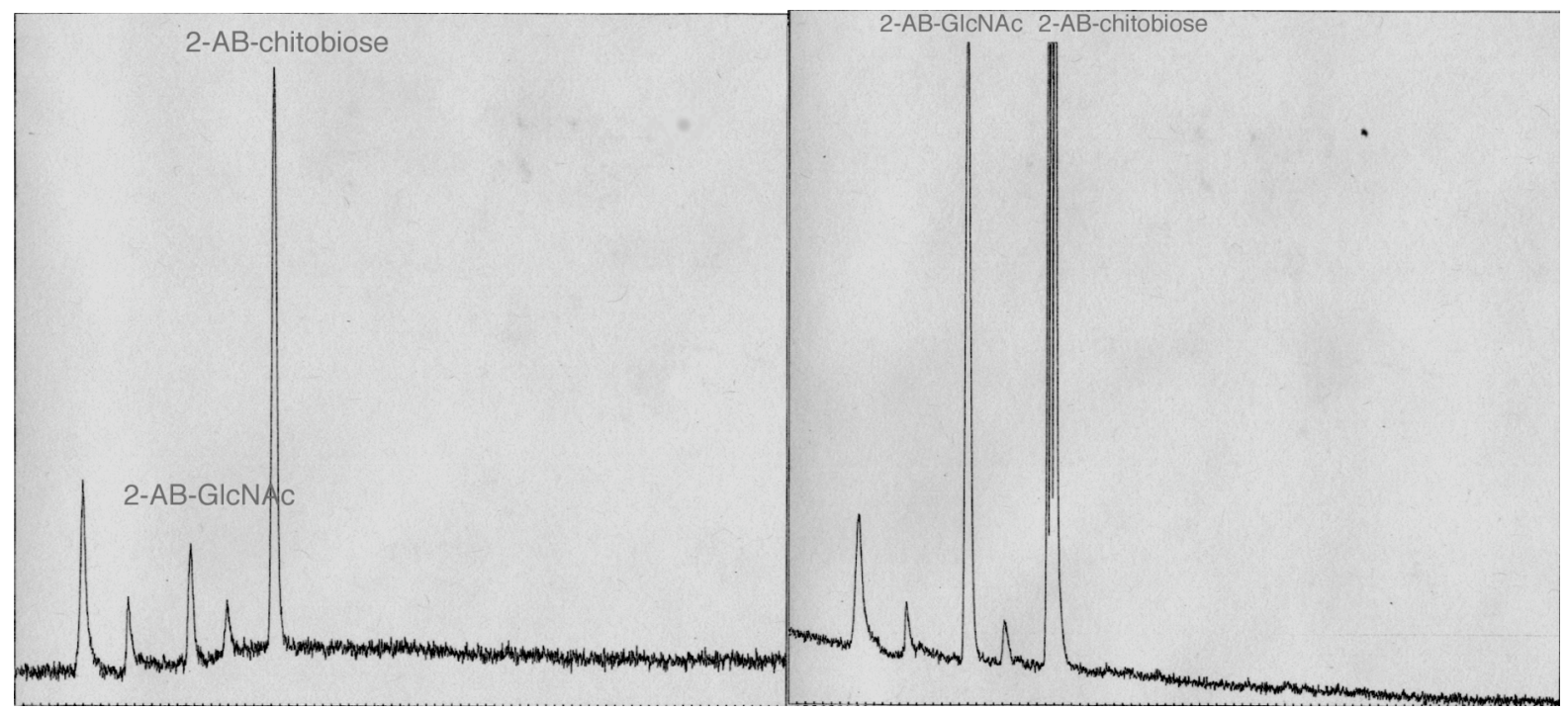

Figure 1: Fluorescence HPLC trace of crude chitobiose at two different concentrations

Pure Chitobiose (4) from chitobioseoctaacetate: Crude chitobiose (5.8 g) was acetylated with acetic anhydride $(65 \mathrm{~mL}, 98 \%$ pure $)$ and anhydrous sodium acetate $(7 \mathrm{~g})$. The reaction was stirred at $80^{\circ} \mathrm{C}$ for 2 days. The product was washed with $\mathrm{NaHCO}_{3}(40 \mathrm{~mL})$ and brine $(50 \mathrm{~mL})$ and recrystallized from $\mathrm{MeOH}$ to obtain $2.4 \mathrm{~g}$ of chitobioseoctaacetate, mainly in the $\alpha$-anomeric form. Recrystallization of the filtrate gave a second batch of $610 \mathrm{mg}$ of $\alpha$-chitobioseoctaacetate. TLC (chitobioseoctaacetate): [silica, 95:5 $\mathrm{CHCl}_{3}: \mathrm{MeOH}$, phosphomolybdenic acid (PMA) detection] $\mathrm{R}_{\mathrm{f}}=0.31$.

Chitobiose octaacetate (372 mg, $0.55 \mathrm{mmol}$ ) and NaOMe (596 mg, $11.0 \mathrm{mmol})$ were dissolved in dry $\mathrm{MeOH}(24 \mathrm{~mL})$ and stirred at room temperature for 3 hours. The reaction was neutralized using Dowex resin (pyridinium form), filtered, concentrated, co-concentrated with toluene, and dried under vacuum overnight.

TLC (unprotected chitobiose): [silica, 4:3:2 ethyl acetate/MeOH/water; $\mathrm{CAM}$ and $10 \% \mathrm{H}_{2} \mathrm{SO}_{4}$ detection] $\mathrm{R}_{\mathrm{f}}=0.73$.

Characterization of $\mathbf{4}$ and chitobioseoctaacetate is in agreement with previous publications. ${ }^{1}$

\section{$1, \beta$-aminochitobiose (1):}

\section{a) From crude chitobiose:}

I) Kochetkov amination: ${ }^{2}$

Saturated ammonium hydrogen carbonate $(27 \mathrm{~mL})$ was added to crude chitobiose $(200 \mathrm{mg})$ and the mixture was stirred at $45^{\circ} \mathrm{C}$ for 2 days. Additional amounts of solid $\mathrm{NH}_{4} \mathrm{HCO}_{3}$ were added after $6 \mathrm{~h}$ and $24 \mathrm{~h}$ to ensure saturation. After 2 days the solution was diluted with water and concentrated to half the volume. This process was repeated (5 times) until no further ammonia was detected. The chitobiosylamine was then repetitively frozen, lyophilized, and dissolved until a constant weight was achieved. Finally, $140 \mathrm{mg}$ of a yellow-white solid were obtained, which was directly used for ${ }^{1} \mathrm{H}-\mathrm{NMR}$ analysis $\left({ }^{1} \mathrm{H}\right.$ NMR spectrum A).

TLC: [silica, 4:3:2 ethyl acetate/MeOH/water; CAM and 10\% $\mathrm{H}_{2} \mathrm{SO}_{4}$ detection] $\mathrm{R}_{\mathrm{f}}=0.73$ (unprotected chitobiose), $\mathrm{R}_{\mathrm{f}}=0.33$ (1, $\beta$-aminochitobiose (1)). 
II) Carbamate amination according to Likhosherstov: ${ }^{3}$

See Experimental Part in Publication for general procedure and characterization. Starting from $420 \mathrm{mg}$ crude chitobiose and $312 \mathrm{mg}$ ammonium carbamate $(4 \mathrm{mmol})$ in $5 \mathrm{~mL} \mathrm{MeOH}, 260 \mathrm{mg}$ $1, \beta$-aminochitobiose (1) $(0.61 \mathrm{mmol})$ were obtained, which corresponds to a yield of $69 \%$, assuming that the crude chitobiose was $90 \%$ pure. For ${ }^{1} \mathrm{H}$ NMR analysis see ${ }^{1} \mathrm{H}$ NMR spectrum B.

\section{b) From pure chitobiose (4):}

Carbamate amination according to Likhosherstov: ${ }^{3}$

The procedure was performed in analogy to the general procedure in the publication. Starting from $420 \mathrm{mg}$ pure chitobiose (4) $(1 \mathrm{mmol})$ and $312 \mathrm{mg}$ ammonium carbamate $(4 \mathrm{mmol})$ in $5 \mathrm{~mL}$

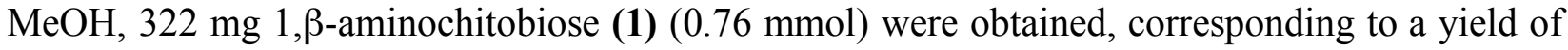
$76 \%$. Characterization was in accordance with the amination with crude chitobiose.

\section{Allyl- $N^{4}$-[2-acetamido-2-deoxy-4-O-(2-acetamido-2-deoxy-3,4,6-tri-O-tertbutyldimethylsilyl- $\beta$-D-glucopyranosyl)-3,6-di- $O$-tert-butyldimethylsilyl- $\beta$-D-glucopyranosyl]- $\boldsymbol{N}^{2}$-(fluoren-9- ylmethoxycarbonyl)-L-aspartate (5):}

Fmoc-Asp-OAll (395 mg, $1 \mathrm{mmol})$ was dissolved in $15 \mathrm{ml}$ DMF. DIPEA (420 $\mu \mathrm{L}, 2 \mathrm{mmol})$, HBTU (1.138 g, $3 \mathrm{mmol}$ ), and HOBt (405 mg, $3 \mathrm{mmol}$ ) were added. 1, $\beta$-aminochitobiose (1), which was obtained from a $2 \mathrm{mmol}$ scale carbamate amination in $5 \mathrm{ml} \mathrm{MeOH}$, was added directly as a solid and the reaction was stirred for $24 \mathrm{~h}$. (Caution: Drying times longer than $10 \mathrm{~s}$ lead to decomposition of the chitobiose amine. However, drying is necessary to reduce the amount of methanol in the reaction mixture, which would lead to formation of the Fmoc-Asp(OMe)-OAll). The DMF was evaporated and $25 \mathrm{~mL}$ ethyl acetate was added, which caused precipitation of the unprotected carbohydrate amino acid. This mixture was stirred for $8 \mathrm{~h}$. The white solid was filtered off, dried under high vacuum, and used for the TBDMS-protection without further purification.

Next, the solid was suspended in $10 \mathrm{~mL}$ dry pyridine, and $18 \mathrm{mg}$ DMAP $(0.15 \mathrm{mmol})$ were added. The reaction was cooled to $0{ }^{\circ} \mathrm{C}$ and $3.6 \mathrm{~mL}$ TBDMS-OTf $(4.14 \mathrm{~g}, 16 \mathrm{mmol})$ was added in three portions over $24 \mathrm{~h}$. After no further conversion was observed by TLC analysis, the reaction mixture was concentrated under high vacuum and directly purified by flash column chromatography yielding $762 \mathrm{mg}$ of $\mathbf{5}(0.56 \mathrm{mmol})$.

TLC: [silica, 3.5:1 $\mathrm{CHCl}_{3} / \mathrm{CH}_{3} \mathrm{CN}$ ] $\mathrm{R}_{\mathrm{f}}=0.55$.

Characterization of $\mathbf{5}$ is in agreement with previous publications. ${ }^{4,5}$

\section{$N^{4}$-[2-acetamido-2-deoxy-4- $O$-(2-acetamido-2-deoxy-3,4,6-tri- $O$-tertbutyldimethylsilyl- $\beta$-D- glucopyranosyl)-3,6-di- $O$-tert-butyldimethylsilyl- $\beta$-D-glucopyranosyl]- $N^{2}$-(fluoren-9-} ylmethoxycarbonyl)-L-aspartic acid (2). A $100 \mathrm{mg}(0.072 \mathrm{mmol})$ portion of compound 5 was dissolved in freshly distilled $\mathrm{CH}_{2} \mathrm{Cl}_{2}(5 \mathrm{~mL}) . \mathrm{Pd}\left(\mathrm{PPh}_{3}\right)_{4}(1.6 \mathrm{mg}, 1.4 \mu \mathrm{mol}, 0.02$ eq.) and $18 \mu \mathrm{l}$ $\mathrm{PhSiH}_{3}$ (15.6 mg, $0.14 \mathrm{mmol}, 2$ eq.) were added and the solution was stirred for $45 \mathrm{~min}$. Water $(0.20 \mathrm{~mL})$ was added and, after another 30 minutes, the solution was concentrated. Flash column chromatography (silica, 95:4.5:0.5 $\mathrm{CHCl}_{3} / \mathrm{MeOH} / \mathrm{AcOH}$ ) followed by size exclusion chromatography (Sephadex LH-20, 2 drops/min, 2:1 $\left.\mathrm{CHCl}_{3} / \mathrm{MeOH}\right)$ afforded $93 \mathrm{mg} 2(0.070$ mmol) in $97 \%$ yield.

Characterization of $\mathbf{2}$ is in agreement previous reports. ${ }^{5}$ 


\section{SPPS of the glycosylated C-peptide analog}

The peptide Y15-G39 was synthesized on an ABI431 automated peptide synthesizer using standard 9-fluorenylmethoxycarbonyl (Fmoc) chemistry. Tentagel ${ }^{\circledR}$ resin $(0.3 \mathrm{mmol} / \mathrm{g})$ was used as the solid support and the couplings were performed using HOBt/HBTU as activators. ${ }^{6}$ The $N$ terminus Fmoc group was deprotected using 20\% piperidine in DMF. For the coupling of the building block 2 and the subsequent 13 amino acid residues, manual couplings were performed. A test cleavage of this peptide revealed a purity of $94 \%$ for the $25 \mathrm{mer}$.

Coupling of building block 2 was achieved with two equivalents of the building block (159 $\mathrm{mg}$, $0.12 \mathrm{mmol}), 4$ equivalents PyAOP $(125 \mathrm{mg}, 0.24 \mathrm{mmol})$ and 8 equivalents collidine $(38.8 \mu \mathrm{L}$, $0.48 \mathrm{mmol}$ ) in $2 \mathrm{~mL} \mathrm{CH} \mathrm{Cl}_{2}$ for $2 \mathrm{~h}$. An acetyl capping step using acetic anhydride (1 mL) and diisopropylethylamine in DMF $(0.195 \mathrm{M}, 3 \mathrm{~mL})$ was performed after the building block coupling. PyAOP/collidine was also used for the coupling of the next two amino acids before the conditions were changed to HOBt/HBTU activation for the remaining 11 amino acid couplings. Each coupling step was monitored by reactivity with TBNS. Test cleavages and HPLC/MS analysis were performed after the coupling of building block 2, as well as the subsequent two amino acids (N13 and I12), and after the attachment of G1, revealing high conversion for all coupling steps. The $\mathrm{N}$-terminally deprotected $\mathrm{C}$-peptide was acetylated with acetic anhydride (1 $\mathrm{mL})$ and diisopropylethylamine in $\operatorname{DMF}(0.195 \mathrm{M}, 3 \mathrm{~mL})$. Some optimization studies were required to find the best conditions for cleaving the peptide off the resin with concomitant sidechain deprotection. Finally, a modified version of the cleavage cocktail K $(82.5 \%$ TFA; $2.5 \%$ EDT; $5 \% \mathrm{PhSMe} ; 5 \% \mathrm{H}_{2} \mathrm{O} ; 150 \mathrm{mg}$ phenol with an additional $100 \mu \mathrm{l}$ of triisopropylsilane (TIS) added) was found to deliver the best peptide yields. The peptide was precipitated from ether, and then purified twice using reversed phase HPLC to ensure homogeneous material for biophysical experiments (YMC-C 18 -preparative column, $\mathrm{H}_{2} \mathrm{O} / \mathrm{CH}_{3} \mathrm{CN}$ with $0.1 \%$ TFA, flow rate: 15 $\mathrm{mL} / \mathrm{min}$ ). The glycosylated C-peptide was first eluted at a steep gradient of $7 \%$ to $95 \% \mathrm{CH}_{3} \mathrm{CN}$ over $35 \mathrm{~min}$. Afterwards, a slow gradient was applied $\left(5 \mathrm{~min}\right.$ constant flow at $7 \% \mathrm{CH}_{3} \mathrm{CN}, 15$ min at $20 \% \mathrm{CH}_{3} \mathrm{CN}$, a gradient from $45 \%$ to $53 \% \mathrm{CH}_{3} \mathrm{CN}$ over $20 \mathrm{~min}$, followed by a gradient from $53 \%$ to $95 \%$ over $5 \mathrm{~min}$ ). The glycosylated C-peptide eluted at 30.8 min using the slow gradient. Figure 2a (see manuscript) displays a representative HPLC trace of the crude peptide product using the slow gradient, revealing a good overall conversion for the peptide synthesis.

The purified peptide was reinjected at a gradient of $7 \%$ to $95 \% \mathrm{CH}_{3} \mathrm{CN}$ over 35 min, which eluted at 27.4 min (See Figure $2 \mathrm{~b}$ in manuscript). MALDI and ESI-MS analysis (Figure 2c) confirmed the glycosylated C-peptide.

$$
\begin{aligned}
& \text { MS }(\mathrm{MALDI})=5152.4(\mathrm{M}+3 \mathrm{H}, \text { observed }) 5149.2(\mathrm{M}, \text { calculated }) \\
& \text { MS }(\mathrm{ESMS})=1288.5\left([\mathrm{M} / 4]^{+}, \text {observed }\right) 1288.4\left([\mathrm{M} / 4]^{+}, \text {calculated }\right)
\end{aligned}
$$


${ }^{1} \mathrm{H}$ NMR spectrum A.

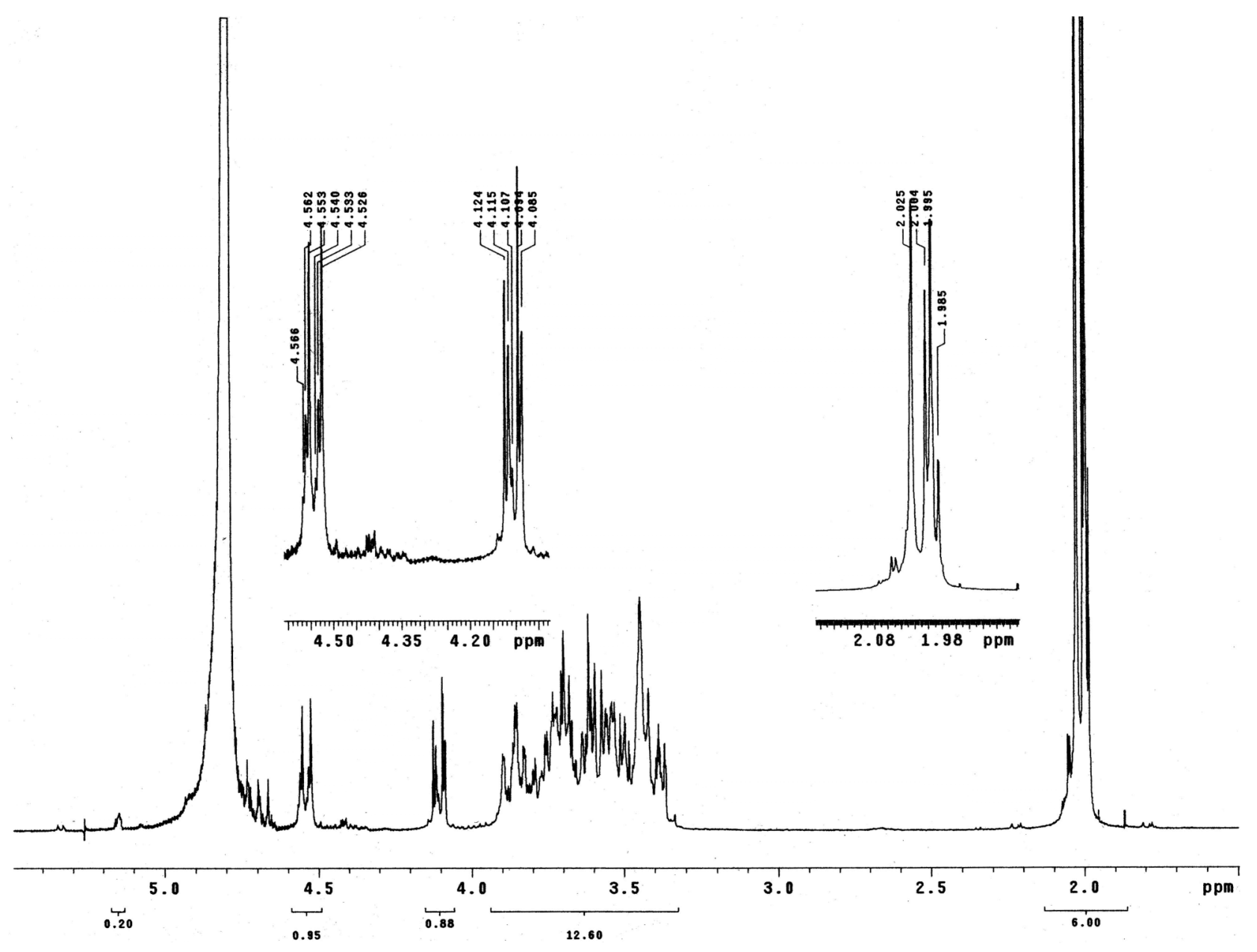


${ }^{1} \mathrm{H}$ NMR spectrum B.

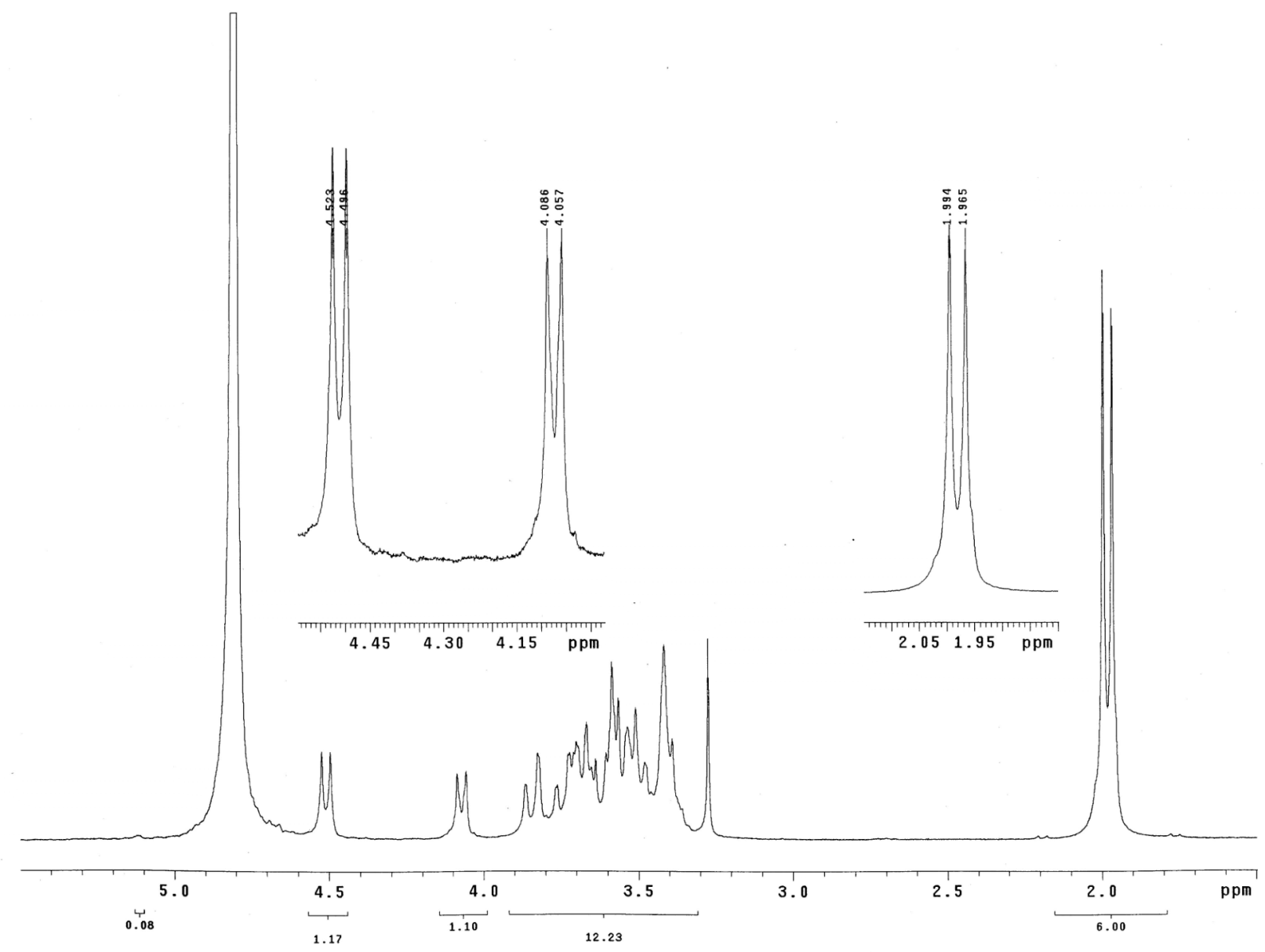

\section{References:}

${ }^{1}$ Terayama, H.; Takahashi, S.; Kuzuhara, H. J. Carbohydr. Chem. 1993, 12, 81.

${ }^{2}$ Likhoshertov, L. M.; Novikova, V. A.; Dervitskaja, V. A.; Kochetkov, N. K. Carbohydr. Res. 1986, 46, C1.

${ }^{3}$ Likhosherstov, L. M.; Novikova, O. S.; Shibaev, V. N. Doklady Chemistry 2002, 383, 89.

${ }^{4}$ Bosques, C. J.; Tai, V. W. F.; Imperiali, B. Tetrahedron Lett. 2001, 42, 7207.

${ }^{5}$ Holm, B.; Linse, S.; Kihlberg, J. Tetrahedron 1998, 54, 11995.

${ }^{6}$ We acknowledge Dr. Michael J. Root for the SPPS of the peptide Y15-G39. 